\title{
Characterization of goat production systems in five states of northeastern Brazil
}

\section{Caracterização dos sistemas de produção de caprinos de cinco Estados no Nordeste}

\author{
Areano Ethério Moreira de Farias ${ }^{1}$; José Romero Alexandre Alves ${ }^{1}$; Francisco \\ Selmo Fernandes Alves²; Raymundo Rizaldo Pinheiro²; Patrícia Yoshida Faccioli- \\ Martins $^{2}$; Ana Milena César Lima ${ }^{3}$; Sérgio Santos Azevedo ${ }^{4}$ Clebert José Alves ${ }^{4 *}$
}

\begin{abstract}
Goat farming is a very important activity contributing to the social and economic development of northeastern (NE) Brazil. The objective of the present study was to characterize the goat farming production system in five of the nine states that constitute the Brazilian NE (Ceará, Paraíba, Piauí, Rio Grande do Norte, and Sergipe). Research was carried out in 230 rural properties located in 62 municipalities of the NE of Brazil, in regions exhibiting a productive arrangement and significant goat population density. An epidemiological questionnaire seeking information on economic, productive, and social aspects of owners/properties was supplied to all properties. The results described the goat farming system in the Brazilian NE as family and subsistence, directed towards domestic consumption and local commerce, and exhibiting a low technological level. The farmers' education level, investments, and technical assistance were all considered low, and thus insufficient or inadequate for a full development of the activity in the region. Therefore, such aspects are suggested to be taken into account in the planning of future goat farming development policies - particularly financing and technical assistance, better preparation of farmers, administrative aspects, forage production and conservation, and the implementation of actions towards reproductive and frequent disease control.
\end{abstract}

Key words: Goat farming. Northeast. Productive characteristics.

\section{Resumo}

A criação de caprinos é uma atividade de grande importância para o Nordeste (NE), contribuindo para o desenvolvimento econômico e social da região. Diante disso, objetivou-se caracterizar o sistema produtivo da caprinocultura em cinco dos nove Estados que compõem o NE brasileiro (Ceará; Paraíba; Piauí; Rio Grande do Norte; Sergipe). A pesquisa foi realizada na região NE do Brasil, em 230 propriedades rurais de 62 municípios oriundos de regiões com arranjo produtivo e densidade populacional significativa de rebanhos caprinos. Nas propriedades foi aplicado questionário epidemiológico, buscando informações sobre aspectos econômicos, produtivos e sociais dos proprietários/propriedades. Os resultados obtidos classificaram o sistema de produção de caprinos no NE brasileiro como familiar e de subsistência,

1 Discentes do Curso de Doutorado, Programa de Pós-Graduação em Ciência e Saúde Animal, Universidade Federal de Campina Grande, UFCG, Patos, PB, Brasil. E-mail: areanomv@yahoo.com.br; j.romeroalves@bol.com.br

2 Pesquisadores, Departamento de Sanidade Animal, Empresa Brasileira de Pesquisa Agropecuária, EMBRAPA Caprinos e Ovinos, CNPC, Sobral, CE, Brasil. E-mail: selmo.alves@embrapa.br; rizaldo.pinheiro@embrapa.br; patricia.yoshida@embrapa.br

3 Discente do Curso de Doutorado, Programa de Pós-Graduação em Ciência Animal, Universidade Federal do Piauí, UFPI, Teresina, PI, Brasil. E-mail: anamilenalima@yahoo.com.br

4 Profs. Titulares, Unidade Acadêmica de Medicina Veterinária, UAMV, Centro de Saúde e Tecnologia Rural, CSTR, UFCG, Patos, PB, Brasil. E-mail: sergio@vps.fmvz.usp.br; clebertja@uol.com.br

* Author for correspondence 
para consumo doméstico e comércio local, com baixo nível de tecnificação. O nível de escolaridade dos criadores foi considerado baixo, bem como dos investimentos e assistência técnica realizadas, insuficientes ou inadequados para o desenvolvimento pleno da atividade na região. Dessa forma, sugere-se que tais aspectos sejam levados em consideração quanto ao planejamento de futuras políticas de desenvolvimento para a caprinocultura, especialmente quando relacionados a financiamento e assistência técnica, no melhor preparo dos criadores, nos aspectos administrativos, de produção e conservação de forragens e na implementação de ações no controle reprodutivo e das doenças mais frequentes.

Palavras-chave: Características produtivas. Caprinocultura. Nordeste.

\section{Introduction}

Goat farming occurs in all five large regions of Brazil, reaching a total of 9,592,079 animals in 2017. The activity is divided into two goat farming variants: the traditional, of great social and cultural importance, that occurs mainly in the Northeast (NE), and; the technological, of greater economic and productive importance and potential for agribusiness (CARVALHO, 2003; IBGE, 2017). The NE region stands out by concentrating $93 \%$ of the national goat population (over nine million animals) distributed in more than one million farming properties, thus consolidating the importance of goat farming in terms of employment and income generation as well as a food source for families in this Brazilian region (SEBRAE, 2009; MOREIRA; GUIMARÃES FILHO, 2011). The rusticity and productive adaptability of goats highlight the production potential of the chain in the NE region, particularly for its socioeconomic development (CARVALHO, 2003).

The increase in consumer demand and great activity of the goat farming production chain in recent years has led to the involvement of states, industry technicians, producers, and industries to seek incentives aimed at improving and consolidating this productive chain in the NE. Examples include credit facilitation, increase in production-focused research, and market incentives to producers, put in place by projects such as: the "Pacto do Novo Cariri" and the "Leite da Paraíba" in the State of Paraíba (BANDEIRA et al., 2007); "Programa do Leite" in Rio Grande do Norte (SILVA, 2014), aimed at the economic development of goat dairy products in these States, and; the "Cabras do Piaui" project, aimed at structuring and developing goat farming in the State of Piauí (EMATER-PI, 2018). Additionally, social projects such as "Cabra Nossa de Cada Dia", aimed to improve basic nutrition access and socioeconomic development of rural communities in the vicinity of Sobral/CE (TEIXEIRA, 2009). However, despite the great concentration of herds, high productive potential, and the sociocultural aspects related to goat husbandry in the NE, research has shown a very limited productive profile for goat farming. These conditions arise from the peculiar circumstances of this chain, including cultural (rusticity of farms), conjectural (prices and markets), and ecological aspects (climate) (RIET-CORREA et al., 2013; SILVA et al., 2013), which limit the development of regional goat farming.

In this context, the activity development is hindered by the lack of pertinent information to enable the characterization of its productive system, conditions that limit the growth potential, and autocorrection of the activity, especially due to a lack of analysis of the socioeconomic and productive profiles of the agricultural production systems (SOUZA, 2009; LIMA et al., 2010). This situation is evidenced by the lack of data regarding the number and location of productive units, and an actual lack of awareness of both the number of farmers and the peculiarities of goat farming. Therefore, the study of the rural reality of various NE Brazil States will generate an important reference tool for the promotion and guidance of current or future development programs that may be applied by institutions responsible for the formulation of public policies, and in the planning and activity of rural extension services in this region. Thus, the objective 
of this study was to characterize the goat farming production systems in the states of Ceará, Piauí, Rio Grande do Norte, Paraíba, and Sergipe.

\section{Materials and Methods}

The Northeast region of Brazil encompasses an area of more than 1.5 million square kilometers (18 $\%$ of Brazilian territory), located below the equator, where the semi-arid climate is prevalent, and the typical biome is Caatinga. It is divided into four sub-regions (Forest Zone, Hinterland, Backlands, and Midnorth), comprising nine Federated States: Alagoas, Bahia, Ceará, Maranhão, Paraíba, Pernambuco, Piauí, Rio Grande do Norte, and Sergipe (SILVA et al., 2010; IBGE, 2017).

The research was carried out on farms from immediate geographic regions located in the five NE Brazilian states with a production pole, a significant goat population density, and a minimum of institutional support structure (e.g. unions, cooperatives, and/or research institutions). The minimum number of properties to be visited was calculated using the formula for simple random samples (THRUSFIELD, 2007), with a sample of $\mathrm{n}=30$ properties per State; however, the final sample comprised 37 properties in Ceará (CE), 62 in Paraíba (PB), 48 in Piauí (PI), 56 in Rio Grande do Norte $(\mathrm{RN})$, and 27 in Sergipe (SE). The following regions were selected: in the state of $\mathrm{CE}$, the metropolitan Fortaleza, Hinterland of Ceará, Northwest of Ceará, and North of Ceará; in PB, Borborema and Sertão of Paraíba; in PI, the Southeast and Center-North; in RN, the Central and West regions; and in SE, the Outback and the Hinterland of Sergipe.

Two-hundred and thirty rural properties in 62 municipalities of the five states were visited (Figure 1). The information was obtained between 2010 and 2012 by applying a questionnaire comprising qualitative and quantitative information, subdivided into sections. The questionnaire was applied to each selected property - goat farming was the criterion adopted for their inclusion, and the selection was based on convenience. The criteria defined for social, economic, and technical issues were the Embrapa Caprinos e Ovinos/CNPC - Sobral / CE database itself, which was created based on studies conducted by a specialized team in the area. The sections were identified as infrastructure, herd, and social and technical variables, with the purpose of obtaining information on property characteristics, producer profiles, and technological levels.

Figure 1. Geographic distribution of the municipalities investigated in the five states of Northeast Brazil (Ceará, Paraíba, Piauí, Rio Grande do Norte, and Sergipe).

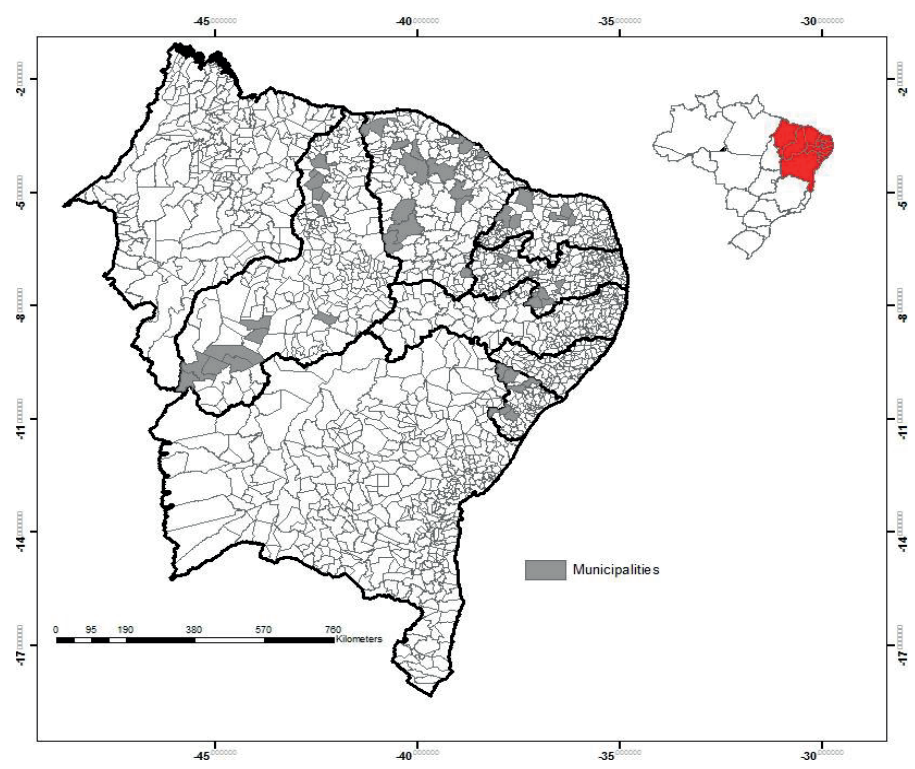


The interview was presented to the interviewee using structured questions to allow the appropriate answers to be obtained for the research objective. The producers were interviewed directly on their properties by EMBRAPA technicians and scholarship awardees, supervised in loco by EMBRAPA researchers. The questions, response options, and questioning sequence were identical for all respondents to ensure that variation between responses arose from the interviewees (rather than interviewers'), seeking to identify and evaluate the main adopted management systems.

A simple frequency analysis was performed on the collected information using the STATISTICA Trial Program (2009).

\section{Results and Discussion}

From the total of the 230 property owners interviewed, the education level of $44.3 \%$ of respondents was primary education (elementary school) and illiteracy among the producers was not significant. This trend was mostly higher in the State of PB (60.7\%), followed by SE (47.3\%), RN (42\%), PI (38.2\%), and CE (32.4\%) (Table 1). The interpretation favors an environment conducive to the training of labor, assimilation of new technologies, and improvements in the economic aptitude of goat farming. However, according to Guilherme et al. (2017), although high school education-level producers are more receptive towards training programs, this condition should be carefully evaluated as the quality of public education in the Brazilian inland cities is limited. The PI and CE states also showed a higher frequency of interviewees with a higher education level above $29 \%$ - whereas SE, RN, and PB exhibited a lower secondary education level. This condition is promising in terms of future improvements and requirements that may become necessary in these properties, be it a greater perception and organization of productive needs (especially those of an administrative nature), or the search for specialized guidance and economic improvements.

Table 1. Analysis of the social profile of goat farmers in the Northeast region of Brazil, 2010-2012.

\begin{tabular}{|c|c|c|c|c|c|c|c|c|c|c|c|c|}
\hline \multirow[t]{2}{*}{ Variables } & \multicolumn{2}{|c|}{ Total (230) } & \multicolumn{2}{|c|}{$\begin{array}{l}\text { Sergipe } \\
(27)\end{array}$} & \multicolumn{2}{|c|}{ Piauí (48) } & \multicolumn{2}{|c|}{$\begin{array}{c}\text { Ceará } \\
(37)\end{array}$} & \multicolumn{2}{|c|}{$\begin{array}{l}\text { Rio Grande } \\
\text { do Norte (56) }\end{array}$} & \multicolumn{2}{|c|}{$\begin{array}{c}\text { Paraíba } \\
(62)\end{array}$} \\
\hline & $\mathrm{N}$ & $\%$ & $\mathrm{~N}$ & $\%$ & $\mathrm{~N}$ & $\%$ & $\mathrm{~N}$ & $\%$ & $\mathrm{~N}$ & $\%$ & $\mathrm{~N}$ & $\%$ \\
\hline \multicolumn{13}{|l|}{ Education Level } \\
\hline Illiterate & 5 & 0 & 0 & 0 & 0 & 0 & 0 & 0 & 5 & 10 & 0 & 0 \\
\hline $\begin{array}{l}\text { Up to 1st grade (elementary } \\
\text { school) }\end{array}$ & 91 & 47.3 & 9 & 47.3 & 18 & 38.2 & 12 & 32.4 & 21 & 42 & 31 & 60.7 \\
\hline Up to Grade 2 (high school) & 64 & 42.1 & 8 & 42.1 & 10 & 21.2 & 11 & 29.7 & 17 & 34 & 18 & 35.2 \\
\hline Superior & 44 & 10.5 & 2 & 10.5 & 19 & 40.4 & 14 & 37.8 & 7 & 14 & 2 & 3.9 \\
\hline \multicolumn{13}{|l|}{ Place of residence } \\
\hline In the city & 87 & 41.2 & 7 & 28 & 32 & 66.7 & 18 & 50 & 17 & 34.6 & 13 & 23.2 \\
\hline At the property & 124 & 58.7 & 15 & 60 & 16 & 33.3 & 18 & 50 & 32 & 65.3 & 43 & 76.7 \\
\hline \multicolumn{13}{|c|}{ Participation in Union/Cooperative } \\
\hline Yes & 133 & 76.4 & - & - & 17 & 36.1 & 26 & 74.2 & 44 & 95.6 & 45 & 100 \\
\hline No & 41 & 23.5 & - & - & 30 & 63.8 & 9 & 25.7 & 2 & 4.3 & 0 & 0 \\
\hline
\end{tabular}




\begin{tabular}{|c|c|c|c|c|c|c|c|c|c|c|c|c|}
\hline \multicolumn{13}{|c|}{ Accounting } \\
\hline Yes & 18 & 8 & 0 & 0 & 1 & 2.1 & 8 & 22.2 & 3 & 5.4 & 6 & 10 \\
\hline No & 207 & 92 & 27 & 100 & 45 & 97.8 & 28 & 77.7 & 53 & 94.6 & 54 & 90 \\
\hline \multicolumn{13}{|c|}{ Acquisition of bank loan } \\
\hline Yes & 112 & 52.5 & 11 & 45.8 & 21 & 46.6 & 14 & 43.7 & 30 & 58.8 & 36 & 59.0 \\
\hline No & 101 & 47.4 & 13 & 54.1 & 24 & 53.3 & 18 & 56.2 & 21 & 41.1 & 25 & 40.9 \\
\hline
\end{tabular}

$\mathrm{N}=$ number of questionnaire replies; $\%=$ percentage of questionnaire replies.

Since goat farming deficiencies may arise from the technical level of the farmers themselves, such as when entrepreneurship, organizational resistance, or the poor perception of the use of new technologies in small ruminant cattle farming were found to be a consequence of the low education level of farmers and other involved agents (SOUZA NETO et al., 1996). Future interventional approaches to the goat farming production chain must necessarily respect the socioeconomic profile and productive reality of each region in order to strengthen the individual potential of each goat farming center. This observation should be considered, since technology usage perceptions may vary with the farmers' level of education, as well as the ease and diligence in the search for assistance and technical support in property management.

The majority of the producers $58.7 \%$ resided on site. This trend was prevalent in PB (76.7\%), RN (65.1\%), and SE (60\%), but not in PI (wherein the majority of respondents $66.7 \%$ lived in cities) nor in CE (50-50\% distribution between city and property dwellers) (Table 1). Living on site contributes to an increase in the time dedicated to goat farming, allowing a daily monitoring of services and streamlining of necessary solutions to address the productive and administrative needs of the property (HOLANDA JUNIOR; CAMPOS, 2003). On the other hand, residing outside the property demands frequent trips from the farmer to attend to daily activities, thus limiting the resolution of specific goat farming aspects, as well as the real-time management and economic losses in the property. In this regard, the importance of both establishing the farmer on the property and adopting public policies to stimulate this (by creating the necessary conditions and opportunities for this settlement) is clear.

A majority of respondents $(52.5 \%)$ claimed they had acquired bank loans for their property, of which $91.5 \%$ had paid their loans off. Most of the bank credit was earmarked for investments and agricultural funding for the property (Table 1); however, the low productive indices did not demonstrate a positive repercussion arising from this practice on properties. Obtaining credit for goat farming activity was frequent in most of the producers evaluated. However, the absence of this practice was also significant (47.4\% of properties), providing evidence of the farmers' concerns about acquiring credit for the goat farming activity. Other activities may aid in meeting investment needs, demonstrating that goat farming may not be the principal income goal for some of the evaluated properties. This situation is often associated with a family agriculture profile, where it is not uncommon for the property owner to have another source of income, such as commerce, agriculture, or an offproperty occupation (SILVA et al., 2013; SILVA, 2014).

Only $8 \%$ of respondents performed accounting, revenue, and expense control of property activities (varying between $22.2 \%$ in $\mathrm{CE}$ and $0 \%$ in SE) (Table 1). The fact that the majority of producers do not perform their activities' accounting shows they were unprepared towards the financial aspects of 
farming, as the realization of this balance is essential for the advancement of any economic activity.

In this study, enrollment in unions and associations was indicated as the main form of organization of producers $(76.4 \%)$, reflected in PB (100 \%), RN (95.6\%), and CE (74.2 \%) (Table $1)$, demonstrating that the farmer community organization in unions and associations is a reality in the rural environment. This shared support space among producers can benefit the composition of these groups in an environment amenable for the intervention of public policies, and as an alternative means for the improvement of owners and workforce (BRITO, 2006). Despite this potential, the social organizations was focused mostly on the social security of union members rather than on developing the productive activity, according to Guilherme et al. (2017). Nonetheless, this social organization is indispensable for farmers to collectivize knowledge and centralize a promising environment to access information on financial institutions, research, and training of micro and small enterprises.

The majority of interviewees $(59.7 \%)$ were individuals aged 31-56 years old, followed by individuals over 57 (27.6\%) (Table 2). The mean age in this study was 47 years, with the oldest farmer being 91 years old; gender-wise, only 6 were women. The higher age of producers may be associated with the migration of younger generations to urban centers in search of better living conditions, emphasizing the necessity of attracting this age group to this market, considering that younger generations are more entrepreneurial and interested in new technologies (HOLANDA JUNIOR; CAMPOS, 2003; LIMA; BAIARDI, 2000). The higher frequency of men and elderly people in NE Brazil goat farming reflects the traditional condition of these producers, wherein the experience and habits of the elders cannot be ignored.

Table 2. Analysis of the quantitative variables: producer age, time in husbandry, and labor destined for goat farming activity in the Northeast region of Brazil, 2010-2012.

\begin{tabular}{|c|c|c|c|c|c|c|c|c|c|c|c|c|}
\hline \multirow{2}{*}{ Variables } & \multicolumn{2}{|c|}{$\begin{array}{l}\text { Total } \\
(230)\end{array}$} & \multicolumn{2}{|c|}{$\begin{array}{l}\text { Sergipe } \\
(27)\end{array}$} & \multicolumn{2}{|c|}{$\begin{array}{l}\text { Piauí } \\
(48)\end{array}$} & \multicolumn{2}{|c|}{$\begin{array}{l}\text { Ceará } \\
\text { (37) }\end{array}$} & \multicolumn{2}{|c|}{$\begin{array}{l}\text { Rio Grande } \\
\text { do Norte (56) }\end{array}$} & \multicolumn{2}{|c|}{$\begin{array}{l}\text { Paraíba } \\
(62)\end{array}$} \\
\hline & $\mathrm{N}$ & $\%$ & $\mathrm{~N}$ & $\%$ & $\mathrm{~N}$ & $\%$ & $\mathrm{~N}$ & $\%$ & $\mathrm{~N}$ & $\%$ & $\mathrm{~N}$ & $\%$ \\
\hline \multicolumn{13}{|l|}{ Age of producer (years) } \\
\hline$\leq 30$ & 26 & 12.6 & 2 & 11.7 & 3 & 6.3 & 3 & 8.8 & 3 & 5.8 & 15 & 25.4 \\
\hline $31-56$ & 123 & 59.7 & 13 & 76.4 & 22 & 46.8 & 22 & 64.7 & 31 & 60.7 & 35 & 59.3 \\
\hline$>57$ & 57 & 27.6 & 2 & 11.7 & 22 & 46.8 & 9 & 26.4 & 15 & 29.4 & 9 & 15.2 \\
\hline \multicolumn{13}{|c|}{ Time in husbandry (years) } \\
\hline$\leq 26$ years & 132 & 59.7 & 19 & 73 & 29 & 60.4 & 23 & 67.4 & 31 & 58.4 & 30 & 50 \\
\hline$>26$ years & 89 & 40.2 & $7 /$ & 26.9 & 19 & 39.5 & 11 & 32.3 & 22 & 41.5 & 30 & 50 \\
\hline \multicolumn{13}{|c|}{$\begin{array}{l}\text { Time dedicated to goat farming } \\
\text { (years) }\end{array}$} \\
\hline$\leq 20$ years & 159 & 71.9 & 21 & 77.7 & 37 & 77 & 20 & 62.5 & 31 & 58.4 & 50 & 81.9 \\
\hline$>20$ years & 62 & 28 & 6 & 22.2 & 11 & 22.9 & 12 & 37.5 & 22 & 41.5 & 11 & 18 \\
\hline \multicolumn{13}{|l|}{ Acquisition of property? } \\
\hline Spot purchase & 94 & 41.9 & 6 & 24 & 25 & 54.3 & 18 & 51.4 & 20 & 36.3 & 24 & 39.3 \\
\hline Financed purchase & 10 & 4.4 & 4 & 16 & 3 & 6.5 & 2 & 5.4 & 1 & 1.8 & 0 & 0 \\
\hline Inheritance & 81 & 36.1 & 6 & 24 & 19 & 41.3 & 8 & 21.6 & 17 & 30.9 & 31 & 50.8 \\
\hline
\end{tabular}




\begin{tabular}{lcccccccccccc} 
continuation & & & & & & & & & & & \\
$\quad$ Settlement & 25 & 11.1 & 6 & 24 & 0 & 0 & 1 & 2.7 & 0 & 0 & 5 & 8.1 \\
$\quad$ & 17 & 7.5 & 3 & 12 & 2 & 4.3 & 7 & 18.9 & 4 & 7.2 & 1 & 1.6 \\
$\quad \begin{array}{l}\text { Other } \\
\text { Family workforce (man/day) }\end{array}$ & & & & & & & & & & & & \\
$\quad$ up to 2 & 169 & 74.7 & 24 & 92.3 & 37 & 78.7 & 27 & 73 & 35 & 63.6 & 46 & 76.6 \\
3 & 26 & 11.5 & 1 & 3.8 & 6 & 12.7 & 5 & 13.5 & 6 & 10.9 & 8 & 13.3 \\
$>3$ & 31 & 13.7 & 1 & 3.8 & 4 & 8.5 & 5 & 13.5 & 15 & 27.2 & 6 & 10 \\
Hired labor (man/day) & & & & & & & & & & & & \\
$\quad 1$ & 144 & 63.7 & 21 & 80.7 & 19 & 40.4 & 16 & 43.2 & 37 & 66.1 & 51 & 85 \\
2 & 31 & 13.7 & 2 & 7.6 & 7 & 14.8 & 9 & 24.3 & 9 & 16.1 & 4 & 6.6 \\
$>2$ & 51 & 22.5 & 3 & 11.5 & 21 & 44.6 & 12 & 32.4 & 10 & 17.9 & 5 & 8.3 \\
Activity training & & & & & & & & & & & & \\
$\quad$ Yes & 80 & 39 & - & - & 8 & 17 & 19 & 51.4 & 20 & 39.2 & 31 & 51.6 \\
No & 125 & 60 & - & - & 9 & 19.1 & 18 & 48.6 & 31 & 60.7 & 29 & 48.3 \\
\hline
\end{tabular}

$\mathrm{N}=$ number of questionnaire replies; $\%=$ percentage of questionnaire replies.

Although women were not shown to be significantly frequent property managers, they have an ever-present role in goat farming and in supporting property activities, a very common trait in family agriculture that is complementary to the masculine work in the property (ALMEIDA et al., 2014). This situation emphasizes the need to attract and work on this segment of the public, since the presence of women in goat farming is an aggregating factor in income, safety, and positive influence on the activity. This is a favorable condition found in goat dairy farming, animal husbandry, diversification, and added value increases of the enterprise production and management (FELISBERTO et al., 2016). Moreover, the activity of women in goat farming may also increase the acceptance of goat farming within families by their greater influence among the younger generations, improving their interaction with the productive and commercial activity of the property.

The majority of the producers have been involved with livestock farming for 26 years or less $(59.7 \%$ ), of which $71.9 \%$ had up to 20 years in goat farming (Table 2); however, the majority of farmers were involved for less than 14 years. The importance of goat farming has grown among farmers over time, demonstrating that the market and financial incentives offered by goat farming programs and projects in the NE yielded positive outcomes with the entry of more producers. Furthermore, most farmers acquired the property by spot purchase or inheritance (41.9\% and 35.2 $\%$, respectively), reflecting both the interest and the traditional aspects in these States. These conditions favor the strengthening and expansion of goat farming in the region - the greater experience in the activity, the greater the chances of effectiveness in the productive performance of the property (FARIA et al., 2004; LIMA et al., 2010).

A family-constituted workforce was more frequently observed than contracted labor. When present, contracted labor complemented the family workforce employed in most cases. When questioned about the level of training of the workforce employed in the property, $39 \%$ of producers stated that they had been given some training (more frequently in the states of PB and CE with $51.6 \%$ and 51.4 $\%$, respectively) (Table 2). The higher training frequency observed in the aforementioned states stems from the presence of research, teaching, and extension institutions, with better technical support and access to information by producers, as well as 
the influence of programs aimed at the development of goat farming in these states, such as the "Pacto do Novo Cariri" and the "Leite da Paraíba" in Paraíba (BANDEIRA et al., 2007). However, pasture production and conservation, sanitary management, and zootechnical records were the least frequently trained aspects in the majority of properties of all states. This condition provides evidence for a lack of knowledge of the actual value of these subjects by goat farmers, which are important for production viability and maintenance of long-term herds (GOMES et al., 2007; NASCIMENTO et al., 2013).

An evaluation of the facilities showed a higher frequency of sheepfolds in the properties $(80.2 \%)$, indicating an interest in the use of technologies that favor goat productive management by the producers (Table 3), since its construction assumes the application of technical recommendations and enables the most appropriate management of the activity (DINIZ et al., 2011). The use of sheepfolds in goat farming has the goal of optimizing the existing workforce labor, benefiting the mananimal-environment relationship throughout the daily activities, providing animal safety and comfort, facilitating sanitary control of the herd, and reducing costs of food waste and stress in productive management. These facilities were cleaned weekly $(46.3 \%)$ or daily $(25.1 \%)$ without the presence of manure pits on most properties; farmers used manure for culture management within their properties. The cleaning of the facilities and the proper directing of goat manure indicate that owners understand that its inappropriate disposal is an enabling factor for the occurrence of diseases within the herd, with a concomitant incurrence in treatment costs and loss of animals and productivity.

Water availability occurred in $70.9 \%$ of properties (Table 3), with the majority of animals having direct access to the source all year round, mainly from reservoirs (58.4\%) and artesian wells (30.4\%). This result is in agreement with that observed in the Northeastern Semi-arid region by Alencar et al. (2010) in properties in the Hinterland in the State of Pernambuco, where the main water resources used in goat farming were reservoirs or wells. The authors drew attention to the necessity of applying technology that enables rainwater storage to meet the demand for the activity throughout most of the year. Most of the farmers in the present study claimed to have this concern, as prolonged drought periods can compromise activity.

Table 3. Analysis of the qualitative variables of the technological aspects favorable to goat farming activities in the Northeast region - Brazil, 2010-2012.

\begin{tabular}{|c|c|c|c|c|c|c|c|c|c|c|c|c|}
\hline \multirow[t]{2}{*}{ Variables } & \multicolumn{2}{|c|}{$\begin{array}{l}\text { Total } \\
(230)\end{array}$} & \multicolumn{2}{|c|}{$\begin{array}{l}\text { Sergipe } \\
\text { (27) }\end{array}$} & \multicolumn{2}{|c|}{$\begin{array}{l}\text { Piauí } \\
(48)\end{array}$} & \multicolumn{2}{|c|}{$\begin{array}{c}\text { Ceará } \\
\text { (37) }\end{array}$} & \multicolumn{2}{|c|}{$\begin{array}{c}\text { Rio Grande } \\
\text { do Norte (56) }\end{array}$} & \multicolumn{2}{|c|}{$\begin{array}{c}\text { Paraíba } \\
(62)\end{array}$} \\
\hline & $\mathrm{N}$ & $\%$ & $\mathrm{~N}$ & $\%$ & $\mathrm{~N}$ & $\%$ & $\mathrm{~N}$ & $\%$ & $\mathrm{~N}$ & $\%$ & $\mathrm{~N}$ & $\%$ \\
\hline \multicolumn{13}{|l|}{ Facilities } \\
\hline Sheepfold & 183 & 80.2 & 20 & 76.9 & 24 & 50 & 26 & 72.2 & 54 & 92.9 & 61 & 98.4 \\
\hline Pig pen & 43 & 18.8 & 0 & 0 & 22 & 45.8 & 19 & 52.7 & 2 & 3.6 & 0 & 0 \\
\hline Forage Silo & 14 & 6.1 & 0 & 0 & 2 & 4.2 & 10 & 27.7 & 2 & 3.6 & 0 & 0 \\
\hline Manure pit & 10 & 4.3 & 1 & 3.8 & 2 & 4.2 & 6 & 16.6 & 1 & 1.8 & 0 & 0 \\
\hline \multicolumn{13}{|c|}{ Cleaning of facilities } \\
\hline No cleaning & 11 & 5.3 & 0 & 0 & 2 & 4.4 & 4 & 11.1 & 3 & 6.5 & 2 & 3.3 \\
\hline Weekly & 96 & 46.3 & 5 & 25 & 18 & 40 & 13 & 36.1 & 24 & 52.1 & 36 & 60 \\
\hline Monthly & 34 & 16.4 & 3 & 15 & 14 & 31.1 & 4 & 11.1 & 10 & 21.7 & 3 & 5 \\
\hline
\end{tabular}


continuation

$\begin{array}{lcccccccccccc}\text { Annually } & 14 & 6.7 & 4 & 20 & 6 & 13.3 & 1 & 2.7 & 3 & 6.5 & 0 & 0 \\ \text { Daily } & 52 & 25.1 & 8 & 40 & 5 & 11.1 & 14 & 38.8 & 6 & 13 & 19 & 31.6\end{array}$

Main water source in the property

\begin{tabular}{lcccccccccccc} 
Protected hand dug well & 19 & 8.6 & 0 & 0 & 3 & 6.8 & 25 & 71.4 & 6 & 11.3 & 0 & 0 \\
Reservoir & 128 & 58.4 & 18 & 69.2 & 19 & 43.1 & 16 & 45.7 & 32 & 60.3 & 43 & 70.4 \\
Well & 71 & 32.4 & 1 & 3.8 & 12 & 27.2 & 4 & 11.4 & 23 & 43.3 & 31 & 50.8 \\
Cistern & 13 & 5.9 & 4 & 15.3 & 1 & 2.2 & 2 & 5.7 & 4 & 7.5 & 2 & 3.2 \\
Artesian well & 18 & 8.2 & 0 & 0 & 11 & 25 & 2 & 5.7 & 4 & 7.5 & 1 & 1.6 \\
River & 33 & 15.0 & 8 & 30.7 & 5 & 11.3 & 10 & 28.5 & 0 & 0 & 10 & 16.3 \\
istribution of water in the premises & & & & & & & & & & & \\
Yes & 156 & 70.9 & 27 & 100 & 17 & 38.6 & 27 & 79.4 & 37 & 69.8 & 48 & 77.4 \\
No & 64 & 29 & 0 & 0 & 27 & 61.3 & 7 & 20.5 & 16 & 30.1 & 14 & 22.5 \\
\hline
\end{tabular}

$\mathrm{N}=$ number of questionnaire replies; $\%=$ percentage of questionnaire replies.

The semi-intensive system predominated among the adopted management systems (62.8\%), except in PI ( $85.3 \%)$ and SE (47.8 \%), where the extensive system predominated (Table 4). Generally, farming systems adopted in the NE vary according to the technology level adopted by the producers; the extensive system is more limiting in goat farming, owing to its low technological level and dependence on rainfall distribution (COSTA et al., 2008; DINIZ et al., 2011). In this context, Guilherme et al. (2017) warned about behavioral changes in the State of PB, considering that the higher frequency of extensive farming would be expected under normal rainfall conditions in NE. However, due to the long drought period the region suffered in recent years, this scenario changed, with farmers being forced to migrate to the semi-intensive management to enable the maintenance of their productive systems. This demonstrates that goat farms managed within the semi-intensive system may be becoming a trend in the Brazilian NE, not only by choice but also by necessity to maintain a viable activity.

Table 4. Analysis of qualitative variables related to facilities and food management that are favorable to goat farming activity in the Northeast region of Brazil, 2010-2012.

\begin{tabular}{|c|c|c|c|c|c|c|c|c|c|c|c|c|}
\hline \multirow[t]{2}{*}{ Variables } & \multicolumn{2}{|c|}{$\begin{array}{l}\text { Total } \\
(230) \\
\end{array}$} & \multicolumn{2}{|c|}{$\begin{array}{l}\text { Sergipe } \\
(27)\end{array}$} & \multicolumn{2}{|c|}{$\begin{array}{l}\text { Piauí } \\
(48)\end{array}$} & \multicolumn{2}{|c|}{$\begin{array}{c}\text { Ceará } \\
(37) \\
\end{array}$} & \multicolumn{2}{|c|}{$\begin{array}{c}\text { Rio Grande } \\
\text { do Norte (56) }\end{array}$} & \multicolumn{2}{|c|}{$\begin{array}{l}\text { Paraíba } \\
(62)\end{array}$} \\
\hline & $\mathrm{N}$ & $\%$ & $\mathrm{~N}$ & $\%$ & $\mathrm{~N}$ & $\%$ & $\mathrm{~N}$ & $\%$ & $\mathrm{~N}$ & $\%$ & $\mathrm{~N}$ & $\%$ \\
\hline \multicolumn{13}{|c|}{ Facilities with technological level } \\
\hline Extensive & 60 & 31.4 & 11 & 47.8 & 35 & 85.3 & 6 & 27.2 & 4 & 7.2 & 4 & 8 \\
\hline Semi-intensive & 120 & 62.8 & 10 & 43.4 & 5 & 12.1 & 9 & 40.9 & 50 & 90.9 & 46 & 92 \\
\hline Intensive & 9 & 4.7 & 2 & 8.6 & 1 & 2.4 & 5 & 22.7 & 1 & 1.8 & 0 & 0 \\
\hline \multicolumn{13}{|c|}{ Goat Feeding Management } \\
\hline NP & 13 & 6.4 & 11 & 50 & 1 & 2.2 & 0 & 0 & 0 & 0 & 0 & 0 \\
\hline $\mathrm{NP}+\mathrm{C}$ & 20 & 9.8 & 3 & 13.6 & 1 & 2.2 & 4 & 19 & 6 & 17.1 & 6 & 10 \\
\hline $\mathrm{CP}+\mathrm{C}$ & 74 & 36.4 & 0 & 0 & 14 & 31.8 & 6 & 28.5 & 19 & 52.2 & 19 & 31.6 \\
\hline $\mathrm{NP}+\mathrm{CP}$ & 12 & 5.9 & 1 & 4.5 & 8 & 18.1 & 0 & 0 & 1 & 2.8 & 1 & 1.6 \\
\hline $\mathrm{NP}+\mathrm{CP}+\mathrm{C}$ & 28 & 13.7 & 7 & 31.8 & 1 & 2.2 & 5 & 23.8 & 4 & 11.4 & 0 & 0 \\
\hline
\end{tabular}


continuation

Goat Feeding Management
NP
$\mathrm{CP}$

Bufell-grass

White leadtree

Native

Elephant grass

Tifton

Brachiaria

Rhodesian grass

Cinodon

Concentrate provided to animals

Yes

No

Forage conservation practices

Yes

Conservation type, if used

Does not use

Haymaking

Pasture

Silage

Rest of Culture
Grazing available for animals

$\begin{array}{cccccccccccc}74 & 36.4 & 21 & 95.4 & 12 & 27.2 & 9 & 42.8 & 11 & 31.4 & 21 & 35 \\ 140 & 68.9 & 8 & 36.3 & 42 & 95.4 & 12 & 57.1 & 25 & 71.4 & 53 & 88.3\end{array}$

$\begin{array}{llllllllllll}39 & 21.3 & 1 & 4.5 & 2 & 4.4 & 0 & 0 & 0 & 0 & 36 & 60\end{array}$

$\begin{array}{llllllllllll}8 & 4.3 & 0 & 0 & 1 & 2.2 & 2 & 9.5 & 5 & 14.2 & 0 & 0\end{array}$

$\begin{array}{llllllllllll}62 & 33.8 & 21 & 95.4 & 11 & 24.4 & 9 & 42.8 & 10 & 28.5 & 11 & 18.3\end{array}$

$\begin{array}{llllllllllll}50 & 27.3 & 2 & 9 & 5 & 11.1 & 7 & 33.3 & 9 & 25.7 & 27 & 45\end{array}$

$\begin{array}{llllllllllll}7 & 3.8 & 0 & 0 & 5 & 11.1 & 0 & 0 & 2 & 5.7 & 0 & 0\end{array}$

$\begin{array}{llllllllllll}31 & 16.9 & 0 & 0 & 10 & 22.2 & 4 & 19 & 6 & 17.1 & 11 & 18.3\end{array}$

$\begin{array}{llllllllllll}32 & 17.4 & 0 & 0 & 31 & 68.8 & 16 & 76.1 & 1 & 2.8 & 0 & 0\end{array}$

$\begin{array}{llllllllllll}72 & 39.3 & 5 & 22.7 & 24 & 53.3 & 8 & 38 & 14 & 40 & 21 & 35\end{array}$

$\begin{array}{cccccccccccc}52 & 92.9 & 12 & 44.4 & 16 & 36.6 & 31 & 86.1 & 52 & 92.9 & 55 & 88.7 \\ 4 & 7.1 & 15 & 55.6 & 28 & 63.6 & 5 & 13.8 & 4 & 7.1 & 7 & 11.3\end{array}$

$\begin{array}{llllllllllll}94 & 42.9 & 13 & 50 & 16 & 35.5 & 18 & 58 & 34 & 60.7 & 13 & 21.3\end{array}$

$\begin{array}{llllllllllll}125 & 57 & 13 & 50 & 29 & 64.4 & 13 & 41.9 & 22 & 39.3 & 48 & 78.6\end{array}$

$\begin{array}{llllllllllll}125 & 57 & 13 & 50 & 29 & 64.4 & 13 & 41.9 & 22 & 39.3 & 48 & 78.6\end{array}$

$\begin{array}{llllllllllll}20 & 9.1 & 0 & 0 & 2 & 4.4 & 3 & 9.6 & 12 & 21.4 & 3 & 4.9\end{array}$

$\begin{array}{llllllllllll}11 & 5 & 0 & 0 & 6 & 13.3 & 4 & 12.9 & 1 & 1.8 & 0 & 0\end{array}$

$\begin{array}{llllllllllll}62 & 28.3 & 11 & 42.3 & 5 & 11.1 & 8 & 25.8 & 28 & 50 & 10 & 16.3\end{array}$

$\begin{array}{llllllllllll}10 & 4.5 & 0 & 0 & 0 & 0 & 9 & 29 & 1 & 1.8 & 0 & 0\end{array}$

\begin{tabular}{lllllllllllll} 
Tree Cactus/Mandacaru/Palm & 2 & 0.9 & 0 & 0 & 0 & 0 & 2 & 6.4 & 0 & 0 & 0 & 0 \\
\hline
\end{tabular}

$\mathrm{PN}=$ native pasture, $\mathrm{CP}=$ cultivated pasture, $\mathrm{FP}=$ forage palm, $\mathrm{C}=$ concentrate; $\mathrm{N}=$ number of questionnaire replies; $\%=$ percentage of questionnaire replies.

Regarding thetypesofbulky foodsand concentrate

Farmers commonly resort to pasture cultivation supplied, the cultivated pasture + concentrate system prevailed, followed by native pasture + cultivated pasture (Table 4). African grasses predominated in cultivated pasture, particularly those better adapted to a semi-arid climate: Bermuda grass (Cynodon dactylon), Elephant grass (Pennisetum purpureum), Buffel-grass (Cenchrus ciliaris), and Ganba grass (Andropogon gayanus). The forage mass yield of some grasses cultivated in the semiarid region is modest due to the low volume and irregularity of rainfall, justifying a search for alternatives (better adapted and more productive forage species and techniques) to meet the nutritional needs of the herd. of grasses mainly in the more humid areas of the property, such as banks, and downstream of dams. Other alternatives, such as the association between native and cultivated pasture on the properties, preparation and elaboration of white leadtree (Leucaena leucocephala) protein banks and their cultivation in conjunction with Buffel-grass or other native species can be used (OLIVEIRA et al., 1988; GUIMARÃES FILHO, 1994; GUIMARÃES FILHO; SOARES, 1999; BANDEIRA et al., 2007), despite it not being the most widely used in the literature. Therefore, the adoption of techniques for the production of intercropped forage species and 
other alternatives, which consider the costs involved and property resources, are good alternatives for the productive viability of farms.

It was observed that $57 \%$ of the producers do not adopt forage conservation practices in the property (Table 4). In general, the production of native forage in the Brazilian NE is insufficient to meet the protein and energy demands of goat farms. Some of the produced forage material goes to waste during the rainy season, whereas in the low rainfall period, a limitation of survival and forage productivity occurs for small ruminants (GOMES et al., 2007; NASCIMENTO et al., 2013). In this respect, it is recommended that, in the dry season, farmers should take advantage of the forage surplus by applying pasture management and conservation techniques, such as silage and haymaking, to allow consumption throughout the greatest shortage period. Although silage and haymaking constitute good forage conservation technique options, properties in the Brazilian NE are not concerned at this level; only RN (50\%) and SE (42.3\%) employed silage to feed the herd. The lack of knowledge about the techniques, the cost of extrafamiliar labor in the different phases of production, and the competition with the production of food for human consumption has justified the disuse of these techniques and the lack of tradition in the storage and conservation of forage by part of the producers (RIET-CORREA et al., 2013). In this context, even with the increasing need for techniques that guarantee the farming productivity throughout drought periods in the Brazilian NE region, misinformation and technical limitations have influenced this choice. It should be noted that the use and approach of these techniques needs to intensify and improve, seeking measures that fit the socio-cultural reality of the producers.

Dairy and dual-use breeds such as the Safflower, Anglo-Nubian, and Chamois Colored stand out in the composition of herds; pure breed animals occur in higher frequency - 80.6\% (Table 5). The predilection for exotic breeds over native animals stems from the greater use of breeders and matrices of these races due to their more productive aspects despite their higher nutritional and management demands (SOUZA et al., 2011). This condition helps with understanding the concern of producers relating to food diversification in the property, as an absence of good nutritional support renders the productive expression of these animals impossible.

Table 5. Analysis of the qualitative and quantitative variables on herd composition and type of agricultural exploration of goat farming in the Northeast region of Brazil, 2010-2012.

\begin{tabular}{|c|c|c|c|c|c|c|c|c|c|c|c|c|}
\hline \multirow[t]{2}{*}{ Variables } & \multicolumn{2}{|c|}{$\begin{array}{l}\text { Total } \\
(230)\end{array}$} & \multicolumn{2}{|c|}{$\begin{array}{l}\text { Sergipe } \\
(27)\end{array}$} & \multicolumn{2}{|c|}{$\begin{array}{l}\text { Piauí } \\
\text { (48) }\end{array}$} & \multicolumn{2}{|c|}{$\begin{array}{l}\text { Ceará } \\
\text { (37) }\end{array}$} & \multicolumn{2}{|c|}{$\begin{array}{c}\text { Rio Grande } \\
\text { do Norte (56) }\end{array}$} & \multicolumn{2}{|c|}{$\begin{array}{c}\text { Paraíba } \\
(62)\end{array}$} \\
\hline & $\mathrm{N}$ & $\%$ & $\mathrm{~N}$ & $\%$ & $\mathrm{~N}$ & $\%$ & $\mathrm{~N}$ & $\%$ & $\mathrm{~N}$ & $\%$ & $\mathrm{~N}$ & $\%$ \\
\hline \multicolumn{13}{|c|}{ Genetic composition of the goat herd } \\
\hline SRD & 43 & 19.3 & 4 & 14.8 & 27 & 60 & 4 & 11.1 & 6 & 11.5 & 2 & 3.2 \\
\hline CRD & 179 & 80.6 & 23 & 85.2 & 18 & 40 & 32 & 88.8 & 46 & 88.4 & 60 & 96.8 \\
\hline \multicolumn{13}{|l|}{ Goat breeds in the property } \\
\hline Saanen & 125 & 56.3 & 21 & 77.8 & 3 & 6.6 & 16 & 44.4 & 37 & 71.1 & 48 & 77.4 \\
\hline Anglo-Nubian & 75 & 33.7 & 10 & 37 & 17 & 37.7 & 35 & 97.2 & 25 & 48 & 8 & 12.9 \\
\hline Boer & 34 & 15.3 & 1 & 3.7 & 16 & 35.5 & 1 & 2.7 & 14 & 31.1 & 2 & 3.2 \\
\hline Chamois Colored & 68 & 30.6 & 7 & 25.9 & 1 & 2.2 & 3 & 8.3 & 15 & 28.8 & 42 & 67.7 \\
\hline Mixed / Crossbreeds & 32 & 14.4 & 6 & 22.2 & 3 & 6.6 & 3 & 8.3 & 6 & 11.5 & 14 & 22.6 \\
\hline Toggenburg & 22 & 9.9 & 0 & 0 & 0 & 0 & 1 & 2.7 & 1 & 1.9 & 20 & 32.3 \\
\hline
\end{tabular}


continuation

$\begin{array}{lcccccccccccc}\text { Moxotó } & 5 & 2.2 & 0 & 0 & 0 & 0 & 4 & 11.1 & 0 & 0 & 1 & 1.6 \\ \text { Canindé } & 5 & 2.2 & 0 & 0 & 0 & 0 & 4 & 11.1 & 1 & 1.9 & 0 & 0 \\ \text { Other } & 9 & 4 & 1 & 3.7 & 5 & 11.1 & 1 & 2.7 & 0 & 0 & 2 & 3.2 \\ \text { ats involved in research } & 5003 & & 500 & & 1354 & & 808 & & 1111 & & 1230\end{array}$

Type of husbandry farming

\begin{tabular}{lcccccccccccc} 
Meat & 86 & 39 & 5 & 21.7 & 42 & 91.3 & 16 & 45.7 & 18 & 33.3 & 5 & 8.1 \\
Milk & 68 & 30.9 & 8 & 34.7 & 2 & 4.3 & 13 & 37.1 & 3 & 5.5 & 42 & 67.7 \\
Mixed & 53 & 24 & 5 & 21.7 & 1 & 2.1 & 0 & 0 & 32 & 59.2 & 15 & 24.2 \\
\hline
\end{tabular}

$\mathrm{N}=$ number of questionnaire replies; $\%=$ percentage of questionnaire replies.

In relation to the type of agricultural holding, properties were predominantly oriented towards meat (39\%), milk (30.9\%), and dual use (24\%) production. The situation differed in PB (67.7\%) and $\operatorname{SE}(34.6 \%)$, where dairy goat production predominated, and in $\mathrm{RN}(59.2 \%)$ with more mixed production properties (Table 5). Nevertheless, the majority of farms are not exclusively oriented towards meat or milk production. In the Brazilian $\mathrm{NE}$, the predominance of subsistence production occurs, with a predisposition of farmers to associate milk production with meat production, a common behavior even in dairy goat farming (VESCHI et al., 2016). In this context, the intervention of the State through social programs that stimulate the production of goat milk becomes very important, as it guarantees the purchase of milk and helps complement income, since the dairy goat has a strong impact on the families in the region (BANDEIRA et al., 2007; SILVA, 2014).

The majority of producers $(70.2 \%)$ did not have the habit of annotating productive, reproductive, or economic events. Those who carried out this procedure $(29.7 \%)$ usually only took notes about reproduction, production, number of animals, and birth (Table 6). This shows the producers' lack of preparation towards the administration and management of the activity, since these notes are vital for the perception of the herd's production and reproductive pattern, and mainly to obtain information on the profitability of the activity and aid in decision making.

The results indicated that $86.4 \%$ of the producers received some kind of technical assistance, largely carried out by a public institution (42.8\%). In PB, assistance was mostly carried out by cooperatives and unions $(68.4 \%)$. The most balanced condition occurred in CE, with Cooperatives/Unions and Public assistance (46.1\%). These aspects highlight the quality of the technical assistance that must be provided to the producers, since basic annotations like the zootechnical control of the herd and the accounting record were not put into practice. The number of farms without reproductive control amounted to $67.6 \%$. Since $86.4 \%$ of the production units received technical assistance, this situation showcases possible failures in transferring assistance to producers (Table 6). It was observed that a lack of information on technical and scientific aspects of reproductive and sanitary management leads to production losses, which discourages the exercise of the small ruminant husbandry (DINIZ et al., 2011). Thus, improvements to the quality and approach of the technical assistance provided to producers should be implemented to allow innovations that exist in research centers (companies and universities) to be put into practice in the properties, with the goal of improving the productive and economic aspects of the activity. 
Table 6. Analysis of qualitative variables of zootechnical aspects of goat farming in the Northeast region of Brazil, 2010-2012.

\begin{tabular}{|c|c|c|c|c|c|c|c|c|c|c|c|c|}
\hline \multirow[t]{2}{*}{ Variables } & \multicolumn{2}{|c|}{$\begin{array}{l}\text { Total } \\
(230)\end{array}$} & \multicolumn{2}{|c|}{$\begin{array}{c}\text { Sergipe } \\
(27)\end{array}$} & \multicolumn{2}{|c|}{$\begin{array}{l}\text { Piauí } \\
(48)\end{array}$} & \multicolumn{2}{|c|}{$\begin{array}{c}\text { Ceará } \\
\text { (37) }\end{array}$} & \multicolumn{2}{|c|}{$\begin{array}{c}\text { Rio } \\
\text { Grande do } \\
\text { Norte (56) }\end{array}$} & \multicolumn{2}{|c|}{$\begin{array}{c}\text { Paraíba } \\
\text { (62) }\end{array}$} \\
\hline & $\mathrm{N}$ & $\%$ & $\mathrm{~N}$ & $\%$ & $\mathrm{~N}$ & $\%$ & $\mathrm{~N}$ & $\%$ & $\mathrm{~N}$ & $\%$ & $\mathrm{~N}$ & $\%$ \\
\hline \multicolumn{13}{|l|}{ Performs zootechnical control } \\
\hline Yes & 67 & 29.7 & 2 & 7.4 & 13 & 28.2 & 21 & 58.3 & 15 & 26.7 & 16 & 26.6 \\
\hline No & 158 & 70.2 & 25 & 92.5 & 33 & 71.7 & 15 & 41.6 & 41 & 73.2 & 44 & 73.3 \\
\hline \multicolumn{13}{|l|}{ Type of zootechnical control } \\
\hline Reproduction & 38 & 16.8 & 2 & 7.4 & 5 & 10.8 & 17 & 47.2 & 11 & 19.6 & 3 & 5 \\
\hline Production & 38 & 16.8 & 0 & 0 & 5 & 10.8 & 15 & 41.6 & 6 & 10.7 & 12 & 20 \\
\hline No. of animals & 33 & 14.6 & 0 & 0 & 6 & 13 & 17 & 47.2 & 4 & 7.1 & 6 & 10 \\
\hline Births & 42 & 18.6 & 2 & 7.4 & 3 & 6.5 & 17 & 47.2 & 11 & 19.6 & 9 & 15 \\
\hline Accounting / revenue / expenditures & 18 & 8 & 0 & 0 & 1 & 2.1 & 8 & 22.2 & 3 & 5.4 & 6 & 10 \\
\hline Other & 15 & 6.6 & 0 & 0 & 1 & 2.1 & 7 & 19.4 & 2 & 3.6 & 5 & 8.3 \\
\hline \multicolumn{13}{|l|}{ Technical assistance? } \\
\hline Yes & 191 & 86.4 & 23 & 85.1 & 37 & 82.2 & 28 & 82.3 & 44 & 80 & 59 & 98.3 \\
\hline No & 30 & 13.5 & 4 & 14.8 & 8 & 17.7 & 6 & 17.6 & 11 & 20 & 1 & 1.6 \\
\hline \multicolumn{13}{|l|}{ Type of technical assistance } \\
\hline Cooperative/Union & 60 & 31.7 & 9 & 40.9 & 10 & 25 & 12 & 46.1 & 2 & 4.5 & 39 & 68.4 \\
\hline Private & 48 & 25.3 & 0 & 0 & 5 & 12.5 & 2 & 7.6 & 17 & 38.6 & 12 & 21 \\
\hline Public & 81 & 42.8 & 13 & 59 & 25 & 62.5 & 12 & 46.1 & 25 & 56.8 & 6 & 10.5 \\
\hline \multicolumn{13}{|l|}{ Type of reproductive technique } \\
\hline Artificial Insemination & 9 & 3.9 & 7 & 25.9 & 2 & 4.2 & 0 & 0 & 0 & 0 & 0 & 0 \\
\hline Controlled natural mount & 76 & 33.6 & 11 & 40.7 & 6 & 12.7 & 15 & 41.6 & 19 & 34.5 & 25 & 40.9 \\
\hline Uncontrolled natural mounds & 153 & 67.6 & 19 & 70.4 & 42 & 89.3 & 20 & 55.5 & 36 & 65.4 & 36 & 59 \\
\hline Embryo transfer & 0 & 0 & 0 & 0 & 0 & 0 & 0 & 0 & 0 & 0 & 0 & 0 \\
\hline Combined & 1 & 0.4 & 0 & 0 & 0 & 0 & 1 & 2.7 & 0 & 0 & 0 & 0 \\
\hline
\end{tabular}

$\mathrm{N}=$ number of questionnaire replies; $\%=$ percentage of questionnaire replies.

As for the sanitary aspect, $75.4 \%$ of the productive units carried out vaccinations (most frequently against rabies and clostridiosis) and wormings (99.1\%) (Table 7). Vaccinations were mostly carried out according to the vaccination calendar. It should be noted that vaccination against foot-and-mouth disease were reported in this study. According to Normative Instruction No. 44 of October $2^{\text {nd }}, 2007$ (BRASIL, 2010), vaccination against foot-and-mouth disease should not be administered to caprine cattle, since they serve as disease sentinels for bovines. Although the majority of interviewees attested to practicing helminthiasis control measures, the disease occurred in most of the properties of the NE region, particularly in SE and CE with a $100 \%$ rate of occurrence (Table 7). It was observed that diarrhea was being interpreted as a problem related to helminthiasis by producers in some States. No consensus was reached among interviewees on the use of worming agents and strategic helminthiasis control in properties, evidencing the impermanence of this management. However, in the current context, it is known that an effective parasitosis control must consider a set of 
factors, including the animal species involved, the prevalence of parasites, pasture used, segregation of animals by age group, and rotation of pasture, with the use of worming agents under appropriate professional guidance to avoid the development of resistance to the active pharmaceutical ingredient (VIEIRA, 2005; COSTA et al., 2011). Another useful and easy-to-apply method for the control of gastrointestinal parasites (Haemonchus contortus) is the Famacha ${ }^{\circledR}$ method, which is efficient in controlling anti-helminthic resistance, reducing the need for applied treatments (SOUZA et al., 2017). Despite the option of the Famacha ${ }^{\circledR}$ method, this method was applied in only four properties in CE. Under these conditions, the parasitic control adopted by the goat farmers of the NE region may be insufficient, jeopardizing the productive efficiency of the properties.

Table 7. Analysis of qualitative variables of zootechnical aspects of goat breeding in the Northeast region of Brazil, 2010-2012.

\begin{tabular}{|c|c|c|c|c|c|c|c|c|c|c|c|c|}
\hline \multirow[t]{2}{*}{ Variables } & \multicolumn{2}{|c|}{$\begin{array}{l}\text { Total } \\
(230)\end{array}$} & \multicolumn{2}{|c|}{$\begin{array}{c}\text { Sergipe } \\
(27)\end{array}$} & \multicolumn{2}{|c|}{ Piauí (48) } & \multicolumn{2}{|c|}{$\begin{array}{c}\text { Ceará } \\
(37)\end{array}$} & \multicolumn{2}{|c|}{$\begin{array}{c}\text { Rio } \\
\text { Grande do } \\
\text { Norte (56) } \\
\end{array}$} & \multicolumn{2}{|c|}{$\begin{array}{l}\text { Paraíba } \\
\text { (62) }\end{array}$} \\
\hline & $\mathrm{N}$ & $\%$ & $\mathrm{~N}$ & $\%$ & $\mathrm{~N}$ & $\%$ & $\mathrm{~N}$ & $\%$ & $\mathrm{~N}$ & $\%$ & $\mathrm{~N}$ & $\%$ \\
\hline \multicolumn{13}{|l|}{ Vaccination } \\
\hline Yes & 169 & 75.4 & 17 & 65.3 & 28 & 60.8 & 29 & 80.5 & 39 & 69.6 & 56 & 93.3 \\
\hline No & 55 & 24.5 & 9 & 34.6 & 18 & 39.1 & 7 & 19.4 & 17 & 30.4 & 4 & 6.6 \\
\hline \multicolumn{13}{|l|}{ Realization of Wormings } \\
\hline Yes & 224 & 99.1 & 27 & 100 & 44 & 95.6 & 36 & 100 & 0 & 0 & 61 & 100 \\
\hline No & 2 & 0.8 & 0 & 0 & 2 & 4.3 & 0 & 0 & 56 & 100 & 0 & 0 \\
\hline \multicolumn{13}{|l|}{ Most frequent diseases } \\
\hline Helminthiasis & 227 & 100 & 27 & 100 & 0 & 0 & 36 & 100 & 0 & 0 & 0 & 0 \\
\hline Diarrhea & 210 & 92.5 & 25 & 92.6 & 38 & 82.6 & 34 & 94.4 & 63 & 94.6 & 60 & 96.8 \\
\hline Caseous lymphadenitis & 206 & 90.7 & 27 & 100 & 36 & 78.2 & 28 & 77.7 & 0 & 0 & 59 & 95.2 \\
\hline Myiasis & 200 & 88.1 & 21 & 77.8 & 39 & 84.7 & 25 & 69.4 & 0 & 0 & 59 & 95.2 \\
\hline Bronchopneumonia & 181 & 79.7 & 27 & 100 & 17 & 36.9 & 31 & 86.1 & 55 & 98.2 & 51 & 82.3 \\
\hline Louse & 129 & 56.8 & 12 & 44.4 & 14 & 30.4 & 21 & 58.3 & 31 & 55.4 & 51 & 82.3 \\
\hline Infectious ecthyma / Angular cheilitis & 119 & 52.4 & 11 & 40.7 & 9 & 19.5 & 21 & 58.3 & 33 & 58.9 & 45 & 72.6 \\
\hline Clostridiosis & 20 & 8.8 & 0 & 0 & 10 & 21.7 & 10 & 27.7 & 0 & 0 & 0 & 0 \\
\hline Anthrax & 12 & 5.2 & 0 & 0 & 2 & 4.3 & 9 & 25 & 1 & 1.8 & 0 & 0 \\
\hline Rabies & 9 & 3.9 & 0 & 0 & 2 & 4.3 & 6 & 16.6 & 1 & 1.8 & 0 & 0 \\
\hline Chillblains / Hoof infection & 168 & 74 & 17 & 63 & 30 & 65.2 & 22 & 61.1 & 46 & 82.1 & 53 & 85.5 \\
\hline
\end{tabular}

$\mathrm{N}=$ number of questionnaire replies; $\%=$ percentage of questionnaire replies.

\section{Conclusion}

The obtained results enable the classification of the goat production system in Northeastern Brazil as family and subsistence, guided towards domestic consumption and local commerce and with low technological levels. The education level of the farmers was considered low, with insufficient or inadequate investment, technical assistance, and training to enable the full development of the activity in the region. Therefore, it is suggested that these aspects should be taken into account in planning future goat farming development policies, particularly those related to financing and 
technical assistance, better preparation of farmers, administrative aspects, forage production and conservation, and in the implementation of actions in reproductive control and the most frequent diseases.

\section{Acknowledgements}

We thank the Coordination for the Improvement of Higher Education Personnel (CAPES), for granting a graduate scholarship, the Animal Health research group of Embrapa Caprinos e Ovinos/CNPC Sobral / CE, for the opportunity and cooperation, and Conselho Nacional de Desenvolvimento Científico e Tecnológico / Ministério da Agricultura, Pecuária e Abastecimento through Public Notice 64/2008 for the financial support of the research.

\section{References}

ALENCAR, S. P.; MOTA, R. A.; COELHO, M. C. O. C.; NASCIMENTO, S. A.; ABREU, S. R. O.; CASTRO, R. S. Perfil sanitário dos rebanhos caprinos e ovinos no sertão de Pernambuco. Ciência Animal Brasileira, Goiânia, v. 11, n. 1, p. 131-140, 2010. DOI: 10.5216/cab. v11i1.4051

ALMEIDA, J. A. T.; NORONHA, C. R. B.; BRITO, E. R. P.; FARIAS, A. R. B.; ANDRADE, H. M. L. S. A invisibilidade parcial do trabalho feminino no campo das atividades produtivas. In: REDOR - PERSPECTIVAS FEMININAS DE GÊNERO: DESAFIOS NO CAMPO DAMILITÂNCIAE DAS PRÁTICAS, 18., 2014, Recife. Anais... Recife: Universidade Federal de Pernambuco, 2014. p. 3740-3750. Disponível em: https://paradoxzero. com/zero/redor/wp-content/uploads/2015/07/19574759-1-PB.pdf. Acesso em: 25 out. 2018.

BANDEIRA, D. A.; CASTRO, R. S.; AZEVEDO, E. O.; MELO, L. S. S.; MELO, C. B. Característica de produção da caprinocultura leiteira na região do cariri na Paraíba. Ciência Veterinária nos Trópicos, Recife, v. 10, n. 1, p. 29-35, 2007.

BRASIL. Ministério da Agricultura, Pecuária e Abastecimento. Instrução Normativa $\mathrm{n}^{\circ} 44$ de 02 de outubro de 2007. Programa Nacional de Erradicação da Febre Aftosa (PNEFA). Diário Oficial [da] União, Brasília, 2010. Seção 1, n. 91. p. 2-10. Disponível em: http://www.agricultura.gov.br/assuntos/sanidade- animal-e-vegetal/saude-animal/programas-de-saudeanimal/febre-aftosa/documentos-febre-aftosa/instrucaonormativa-mapa-no-44-de-02-de-outubro-de-2007.pdf/ view. Acesso em: 25 mar. 2018.

BRITO, V. A. O espaço agrário da ovinocaprinocultura no sertão noroeste de Sergipe no período de 1980 a 2003. 2006. Dissertação (Mestrado em Geografia) - Fundação Universidade Federal de Sergipe, Aracaju.

CARVALHO, R. B. Potencialidades dos mercados para os produtos derivados de caprinos e ovinos. In: WORKSHOP SOBRE INTEGRAÇÃO DA CAPRINOVINOCULTURA COM A BOVINOCULTURADELEITENAREGIÃO SUDESTE DOBRASIL, JUIZDEFORA,MG;WORKSHOPSOBRE INTEGRAÇÃO DA CAPRINOVINOCULTURA COM A BOVINOCULTURA DE LEITE NA REGIÃO SUDESTE DO BRASIL, 1., 1., 2003, Juiz de Fora. Anais... Juiz de Fora: EMBRAPA Gado de Leite, 2003. p. 29-53. Disponível em: http://atividaderural.com.br/ artigos/4f7b556526852.pdf. Acesso em: 25 mar. 2018.

COSTA, R. G.; ALMEIDA, C. C.; PIMENTA FILHO, E. C.; HOLANDA JÚNIOR, E. V.; SANTOS, N. M. Caracterização do sistema de produção caprina e ovina na região semiárida no Estado da Paraíba, Brasil. Archivos de Zootecnia, Córdoba, v. 57, n. 218, p. 195-205, 2008.

COSTA, V. M. M.; SIMÕES, S. V. D.; RIET-CORREA, F. Controle das parasitoses gastrintestinais em ovinos e caprinos na região semiárida do Nordeste do Brasil. Pesquisa Veterinária Brasileira, Seropédica, v. 31, n. 1, p. $65-71,2011$. DOI: $1590 / \mathrm{S} 0100-736 \mathrm{X} 2011000100010$

DINIZ, B. L. M. Estudo zoosanitário da Caprinocultura $e$ da ovinocultura, soroprevalência das lentiviroses de pequenos ruminantes na microrregião do alto médio gurguéia, na Região Sul do Piauí. 2011. Tese (Doutorado em Ciência Animal) - Universidade Federal do Piauí, Teresina.

FARIA, G. A.; MORAIS, O. R.; GUIMARAES, P. H. S. Análise da ovinocaprinocultura no norte e nordeste de minas gerais. Belo Horizonte: SEBRAE, MG, FAEMG, EMATER, 2004. 122 p. Disponível em: http:// propi.ifto.edu.br/ocs/index.php/connepi/vii/paper/ viewFile/3759/1950. Acesso em: 15 mar. 2018.

FELISBERTO, N. R. O.; OLIVEIRA, L. S.; CORDEIRO, A. G. P. C. Sistemas de produção de caprinos leiteiros. Sobral: EMBRAPA Caprinos e Ovinos, 2016. 97 p. (Comunicado Técnico, EMBRAPA Caprinos e Ovinos). Disponível em: https://www.alice.cnptia. embrapa.br/alice/bitstream/doc/1064921/1/CNPC2016 Sistemasdeproducao.pdf. Acesso em: 15 maio 2018. 
GOMES, J.A. F.; LEITE, E. R.; RIBEIRO, T. P. Alimentos $e$ alimentação de ovinos e caprinos no semi-árido brasileiro. Sobral: EMBRAPA Caprinos e Ovinos, 2007. 97 p. (Documentos, EMBRAPA Caprinos e Ovinos, 67). Disponível em: https://www.infoteca.cnptia.embrapa.br/ infoteca/bitstream/doc/533703/1/ doc67.pdf. Acesso em: 12 maio 2018.

GUILHERME, R. F.; LIMA, A. M. C.; ALVES, J. R. A.; COSTA, D. F.; PINHEIRO, R. R.; ALVES, F. S. F.; AZEVEDO, S. S.; ALVES, C. J. Caracterização dos sistemas de produção de ovinos e caprinos no estado da Paraíba, semiárido do Nordeste, Brasil. Semina: Ciências Agrárias, Londrina, v. 38, n. 4, p. 2163-2178, 2017. DOI: $10.5433 / 1679-0359.2017 \mathrm{v} 38 \mathrm{n} 4 \mathrm{p} 2163$

GUIMARÃES FILHO, C. Efeito do pastejo suplementar em capim buffel durante o período seco na taxa anual de parição de vacas criadas na caatinga. Pesquisa Agropecuária Brasileira, Brasília, v. 29, n. 1, p. 139-143, 1994.

GUIMARÃES FILHO, C.; SOARES, J. G. G. Avaliação de um modelo físico de produção de bovinos no semiárido integrando caatinga, capim buffel e leucena. Pesquisa Agropecuária Brasileira, Brasília, v. 34, n. 9, p. 17211727, 1999. DOI: 10.1590/S0100-204X1999000900024

HOLANDA JUNIOR, F. I. F.; CAMPOS, R. T. Análise técnico econômica da pecuária leiteira no município de Quixeramobim-Ceará. Revista Econômica do Nordeste, Fortaleza, v. 34, n. 4, p. 621-646, 2003.

INSTITUTO BRASILEIRO DE GEOGRAFIA E ESTATÍSTICA - IBGE. Pesquisa pecuária municipal. Rio de Janeiro: IBGE, 2017. Disponível em: https://sidra. ibge.gov.br/pesquisa/ppm/quadros/brasil/2017. Acesso em: 12 mar. 2018.

INSTITUTO DE ASSISTÊNCIA TÉCNICA E EXTENSÃO RURAL DO PIAUÍ - EMATER-PI. Projeto Cabra do Piauí. Teresina: EMATER/PI, 2018. Disponível em: http://www.emater.pi.gov.br/cabras.php. Acesso em: 10 mar. 2018.

LIMA, A. M. C.; FARIAS, D. A.; LANTIAGO, L. B.; CAVALCANTE, A. C. R.; ALVES, F. S. F.; PINHEIRO, R. R. Caracterização dos produtores de caprinos e ovinos das mesorregiões metropolitana de Fortaleza e dos sertões cearenses. In: CONGRESSO NORDESTINO DE PRODUÇÃO ANIMAL, 6., 2010, Mossoró. Anais... Mossoró: Universidade Federal do Semiárido, UFERSA, 2010. p. 1-6. Disponível em: https://www. embrapa.br/busca-de-publicacoes/-/publicacao/870296/ caracterizacao-dos-produtores-de-caprinos-e-ovinosdas-mesorregioes-metropolitana-de-fortaleza-e-dossertoes-cearenses. Acesso em: 10 jul. 2018.
LIMA, R. G. S.;BAIARDI,A.Estratégias de sobrevivência dos pequenos caprinocultores do semiárido baiano. In: CONGRESSO BRASILEIRO DE ECONOMIA E SOCIOLOGIA RURAL. A AGRICULTURA NO LIMIAR DO MILÊNIO, 38., 2000, Brasília. Anais eletrônicos... Brasília: SOBER, 2000. p. 26-30.

MOREIRA, J. N.; GUIMARÃES FILHO, C. Sistemas tradicionais para a produção de caprinos e ovinos. In: VOLTOLINI, T. V. (Ed.). Produção de caprinos e ovinos no semiárido. Petrolina: EMBRAPA Semiárido, 2011. Cap. 2, p. 49-68. Disponível em: https://www.embrapa. br/busca-de-publicacoes/-/publicacao/ 916893/sistematradicionais-para-a-producao-de-caprinos-e-ovinos. Acesso em: 14 maio 2018.

NASCIMENTO, M. C. O.; SOUZA, B. B.; SILVA, F. V.; MELO, T. S. Armazenamento de forragem para caprinos e ovinos no semiárido do Nordeste. Revista Cientifica do Semiárido, Patos, v. 9, n. 4, p. 20-27, 2013. DOI: 10.30969/acsa.v9i4.374

OLIVEIRA, M. C.; SILVA, C. M. M.; ALBUQUERQUE, S. G.; BERNARDINO, F. A. Comportamento de gramíneas forrageiras sob condições de pastejo intensivo por bovinos na região semi-árida do nordeste do Brasil. Petrolina: EMBRAPA Semiárido, 1988. 15 p. (Documentos, EMBRAPA Semiárido, 56). Disponível em: $\quad$ https://www.embrapa.br/semiarido/busca-depublicacoes/-/publicacao/132752/comportamentode-gramineas-forrageiras-sob-condicoes-de-pastejointensivo-por-bovinos-na-regiao-semi-arida-donordeste-do-brasi. Acesso em: 14 maio 2018.

RIET-CORREA, B.; SIMÕES, S. V. D.; PEREIRA FILHO, J.M.;AZEVEDO, S. S.; MELO, D. B.; BATISTA, J. A.; MIRANDA NETO, E. G.; RIET-CORREA, F. Sistemas produtivos de caprinocultura leiteira no semiárido paraibano: caracterização, principais limitantes e avaliação de estratégias de intervenção. Pesquisa Veterinaria Brasileira, Seropédica, v. 33, n. 3, p. 45-352, 2013. DOI: 10.1590/S0100-736X2013000300012

SERVIÇO BRASILEIRO DE APOIO ÀS MICRO E PEQUENAS EMPRESAS - SEBRAE. Manejo básico de ovinos e caprinos. Brasília: SEBRAE, 2009. 10 p. Disponível em: https://www.caprilvirtual.com.br/ Artigos/ManejoBasicoOvinoCaprinoSebrae.pdf Acesso em: 10 mar. 2018.

SILVA, E. M. N.; SOUZA, B. B.; SILVA, G. A.; AZEVEDO, S. S.; GOMES, T. L. S. Caracterização dos sistemas produtivos de leite de cabra nos cariris paraibano. Revista Caatinga, Mossoró, v. 26, n. 1, p. 6371, 2013.

SILVA, L. F. N. Perfil de produtores da associação de criadores de cabras leiteiras do leste e agreste potiguar. 
2014. Dissertação (Mestrado em Produção Animal) Universidade Federal do Rio Grande do Norte, Macaíba, Brasil.

SILVA, P. C. G.; MOURA, M. S. B.; KIILL, L. H. P.; BRITO, L. T. L.; PEREIRA, L. A.; SA, I. B.; CORREIA, R. C.; TEIXEIRA, A. H. C.; CUNHA, T. J. F.; GUIMARÃES FILHO, C. Caracterização do Semiárido brasileiro: fatores naturais e humanos. In: SÁ, I. B.; SILVA, P. C. G. Semiárido brasileiro: pesquisa, desenvolvimento e inovação. Petrolina: EMBRAPA Semiárido, 2010. 402 p. (Documentos, EMBRAPA Semiárido). Disponível em: https://www. embrapa.br/busca-de-publicacoes/-/publicacao/ 861906/ caracterizacao-do-semiarido-brasileiro-fatores-naturaise-humanos. Acesso em: 25 out. 2018.

SOUZA NETO, J.; BAKER, G. A.; SOUSA, F. B. Caprinocultura de duplo propósito no Nordeste do Brasil: avaliação do potencial produtivo. Sobral: EMBRAPA Caprinos e Ovinos, 1996. (Comunicado Técnico, EMBRAPA Caprinos e Ovinos). Disponível em: https://www.embrapa.br/busca-de-publicacoes/-/ publicacao/514760/caprinocultura-de-duplo-propositono-nordeste-do-brasil-avaliacao-do-potencial-produtivo. Acesso em: 13 maio 2018.

SOUZA, A. P.; SALES, A. Y; PAZDIORA, R. D.; SANTOS, A. S.; MENEGUELLI, M.; MUNIZ, I. M. Estudo sobre a eficiência do método Famacha® no tratamento seletivo de ovinos. Médica Veterinária na Clínica Animed, Rolim de Moura, v. 6, n. 1, p. 1-62, 2017.

SOUZA, B. B.; SILVA, E. M. N.; SIlvA, G. A.; NOGUEIRA, F. R. B. Leite de cabra: raças utilizadas e sistemas de alimentação utilizados no cariri paraibano. Patos: Universidade Federal de Campina Grande, UFCG, 2011. 5 p. Disponível em: http://www.cstr.ufcg.edu.br/ bioclimatologia/artigos_tecnicos/leite_cabra__racas utilizadas_sistemas_alimentacao.pdf. Acesso em: $1 \overline{4}$ maio $201 \overline{8}$.

SOUZA, M. E. C. Diagnóstico do sistema produtivo dos ovinocaprinocultores do município de Itinga, Médio Vale do Jequitinhonha - MG. Revista Brasileira de Agroecologia, Porto Alegre, v. 4, n. 2, p. 3529-3532, 2009.

STATISTICA Trial Version for Windows (version 9.0). Tulsa: StatSoft Inc., 2009.

TEIXEIRA, R. Cabra nossa de cada dia. Sobral: Universidade Estadual do Vale do Acaraú, UVA, 2009. $152 \mathrm{p}$.

THRUSFIELD, M. Veterinary epidemiology. $3^{\text {th }}$ ed. Oxford: Blackwell Science, 2007. 624 p.

VESCHI, J. L. A.; CAVALCANTE, M. B.; SILVA, W. E. L.; COSTA, M. M. Caracterização de propriedades de criação de caprinos leiteiros localizadas em Petrolina, PE e Santa Maria da Boa Vista, PE. Petrolina: EMBRAPA Semiárido, 2016. 20 p. (Documentos, EMBRAPA Semiárido, 273). Disponível em: https://www.embrapa. br/busca-de-publicacoes/-/publicacao/1056533/ caracterizacao-de-propriedades-de-criacao-de-caprinosleiteiros-localizadas-em-petrolina-pe-e-santa-maria-daboa-vista-pe. Acesso em: 19 maio de 2018.

VIEIRA, L. S. Endoparasitoses gastrintestinais em caprinos e ovinos. Sobral: EMBRAPA Caprinos e Ovinos, 2005. 31 p. (Documentos, EMBRAPA Caprinos e Ovinos, 58). Disponível em: https://www. embrapa.br/busca-de-publicacoes/-/publicacao/533317/ endoparasitoses-gastrintestinais-em-caprinos-e-ovinos. Acesso em: 14 maio 2018. 
